\title{
Core Description and a Preliminarily Sedimentology Study of Site 1202D, Leg 195, in the Southern Okinawa Trough
}

\author{
Chi-Yue Huang ${ }^{1, *}$, Ya-Ling Chiu ${ }^{1}$, and Meixun Zhao ${ }^{1,2}$ \\ (Manuscript received 15 August 2004, in final form 8 November 2004)
}

\begin{abstract}
ODP Site 1202 of Leg 195 was designed primarily for a high-resolution study of the paleoceanography of the Kuroshio Current in the southern Okinawa Trough off NE Taiwan. Four holes were drilled in which Hole 1202D is described in detail in this study for an assessment of core quality for paleoceanography study and understanding of sedimentological features, especially turbidite sedimentation and the sediment provenances during the Late Quaternary in the southern Okinawa Trough. Pelagic mud with insignificant silt or sand layers is observed from the core top down to $133 \mathrm{~m}$ (mbsf; Marine Isotope Stages 1-3), but the silt-sand layer ratio (SLR: total thickness of silt and sand layers / $1.5 \mathrm{~m}$ of core) increases gradually from a value of $<10 \%$ between 133 and $167 \mathrm{~m}$ to values $>50 \%$ between 223 and $279 \mathrm{~m}$, followed by decreases to values $<10 \%$ between 310 and $337 \mathrm{~m}$ and to $<3 \%$ between 337 and $407 \mathrm{~m}$ (Stage 4). These silt-sand layers were most likely derived by fine-grained turbidite gravity flows, which were very active during Stages 3 and 4. Slate fragments, quartz grains, mica flakes and volcanic detritus are the major components in the coarse fraction of wash residues $(>250 \mu \mathrm{m})$. Slate fragments are commonly found in fine-grained turbidite dominant intervals $(160-280 \mathrm{~m})$, while mica flakes can be observed in the muds throughout the core. The major detrital components were derived primarily from the Miocene slate belt of the pre-collision accretionary prism of the Central Range in northern Taiwan. The occurrence of volcanics could represent submarine volcanic activity in the active-opening Okinawa Trough back-arc basin off NE Taiwan. Shallow-marine fossils including benthic foraminifers, echinoids, bryozoans and mollusks are also found in the fine-grained turbidite dominant intervals. These fossil
\end{abstract}

\footnotetext{
${ }^{1}$ Department of Earth Sciences, National Cheng Kung University, Tainan, Taiwan, ROC

2 Department of Earth Sciences, Dartmouth College, Hanover, USA

* Corresponding author address. Prof. Chi-Yue Huang, Department of Earth Sciences, National Cheng Kung University, Tainan, Taiwan, ROC; E-mail: huangcy@mail.ncku.edu.tw
} 


\begin{abstract}
assemblages could have been deposited in the shallow shelf and then transported to the depositional site along with voluminous terrigenous materials derived from Taiwan, via submarine channels or by slope failures due to frequent earthquakes induced by plate convergence/collision and extension in the southwestern Okinawa Trough off NE Taiwan. It is concluded that the top $133 \mathrm{~m}$ of the core is better suited for paleoceanographic reconstruction.
\end{abstract}

\title{
(Key words: Okinawa Trough, Turbidite sedimentation, Central Range, Taiwan, Paleoceanography)
}

\section{INTRODUCTION}

Site $1202\left(24^{\circ} 48.24^{\prime} \mathrm{N}, 122^{\circ} 30.00^{\prime} \mathrm{E}\right.$, water depth $\left.1274 \mathrm{~m}\right)$, Leg 195 , was designed for a high-resolution paleoceanographic study of the Kuroshio Current in the Western Pacific (Shipboard Scientific Party, 2002). The site is located near the southwestern tip of the activeopening back-arc basin Okinawa Trough off NE Taiwan (Fig. 1). More than 800 meters of deep-sea sediments in 4 holes were drilled (Holes 1202A, B, C, and D). Hole A, Hole B, Hole $\mathrm{C}$ and the upper part of Hole D were recovered by using APC core; while the lower part of Hole 1202D was drilled using XCB coring method (Shipboard Scientific Party 2002). Magnetic susceptibility of the four holes was measured on board JOIDES Resolution providing an independent physical property for core correlation. However, most cores were not described in details onboard because of the short time interval before $R / V$ JOIDES Resolution arriving at the next site of Leg 196. Therefore, the purposes of this paper are to present the core description of Hole D, the longest record of the four holes, and give preliminary results for the sedimentological study of the silt-sand layers and their detritus compositions in the coarse fraction of wash residues $(>250 \mu \mathrm{m})$ for better evaluation of core quality in preparation for a highresolution study of the paleoceanography of the Kuroshio Current (Wei et al. 2005; Zhao et al. 2005).

\section{METHODS}

The working half of Hole 1202D was examined for this description under stereomicroscope (X60-120) at TAMU core lab. The description focuses on occurrence of silt and sand layers in the sequence. Notes were carefully taken on any visible turbidite structures, such as grain size, grading, basal erosion, cross-ripples, detritus compositions, and fossil remains. Silt-sand ratio (SLR) in each $1.5 \mathrm{~m}$ section of core is calculated for an evaluation of core quality for paleoceanographic study and for a better understanding of their depositional mechanisms. Terrigenous detritus in wash residues $(>250 \mu \mathrm{m})$ in 120 samples (average of sampling interval: $3.4 \mathrm{~m}$ ) were also determined under stereo-microscope (X60) for evaluating the source of sediments. An age model based on oxygen isotope stratigraphy and AMS ${ }^{14} \mathrm{C}$ dating by Wei et al. (2005) was followed. 


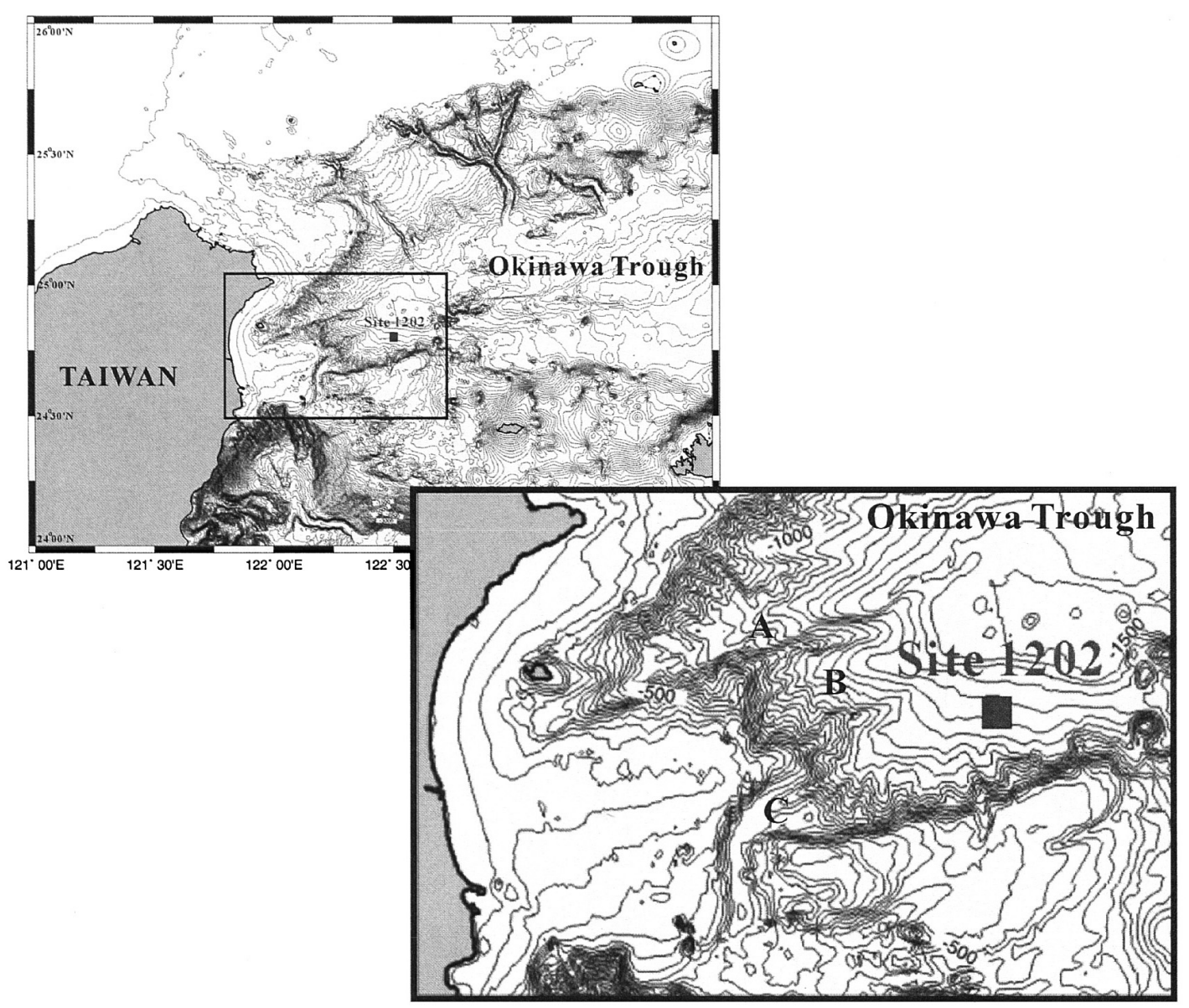

Fig. 1. Site location of Hole 1202D, Leg 195, in the southern Okinawa Trough off NE Taiwan.

\section{RESULTS}

\subsection{Core Description}

Description of each section of core is printed in this volume. The sedimentary feature details of each section can be found in the appendix.

\subsubsection{Cores 1-3 (0 - $19.2 \mathrm{mbsf})$}

Cores 1-3 are exclusively of hemipelagic mud without any visible silt-sand layer (Appendix Fig. 1). 


\subsubsection{Core 4 (19.2 - 29.38 mbsf $)$}

Core 4 is composed of hemipelagic mud with insignificant thin layers of very fine sand and silt (Appendix Fig. 2). A fine sand layer in $37-39 \mathrm{~cm}$ of section 1, associated with echinoid spines and plates, foraminifers and slate chips could be correlated with a fine sand layer in $87-90 \mathrm{~cm}$ of section 1, Core 4 of Hole 1202B. Above this key bed, there is no silt-sand layer in either Hole 1202B or Hole 1202D. Three graded fine sand layers and wood remains, echinoid plates and a gastropod can be observed in section 3. Bivalve fragments with slates in a thin fine sand layer $(83.4-84.6 \mathrm{~cm}$, section 5) provide another key interval for a correlation between core 4 of Hole 1202D and a fine sand layer (70 - $71.5 \mathrm{~cm}$ section 4), Core 4 of Hole 1202B. Small scaphopods Dentalium shells are commonly found in mud intervals of section 6.

\subsubsection{Core 5 (28.7 - 38.5 mbsf $)$}

Core 5 is primarily composed of hemipelagic mud with insignificant turbidite sand layers in sections 1, 2 and 4 (Appendix Fig. 3). Basal erosion and grading features are observed in these turbidite layers in which slate chips, mica flakes and quartz grains are commonly found. Very fine sand layers occur more frequently in the lower part (sections 6, 7 and core CC) of Core 5.

\subsubsection{Core 6 (38.2 - 48.63 mbsf)}

Core 6 is predominated by hemipelagic mud with some very thin layers $(<0.1 \mathrm{~cm})$ of whitish silt to very fine sand (Appendix Fig. 4). Quartz grains are commonly found in these very fine sand layers. Slate chips are rather abundant in a fine sand layer $(78.2-79.4 \mathrm{~cm})$ of section 4.

\subsubsection{Core 7 (47.7 - $58.14 \mathrm{mbsf})$ and Core 8 (57.2 - $67.5 \mathrm{mbsf})$}

The lithology of Core 7 (Appendix Fig. 5) and Core 8 (Appendix Fig. 6) is very similar to Core 6 in which some very fine sand layers $(e a c h<0.1 \mathrm{~cm}$ ) intercalate within hemipelagic mud. The remains of some wood can be observed at $48 \mathrm{~cm}$ in section 3 of Core 7 .

\subsubsection{Core $9(66.7$ - $77.04 \mathrm{~m})$}

Core 9 is almost exclusively of hemipelagic muds (Appendix Fig. 7).

\subsubsection{Core 10 (76.2 $-79.74 \mathrm{mbsf})$}

Core 10 (Appendix Fig. 8) is generally composed of mud with three layers of very fine sand in section 1 and a pumice layer for $3 \mathrm{~cm}(34-37 \mathrm{~cm})$ in section 3 . Some isolated pumice grains are also observed in section 3 . The occurrence of these pumice layers and grains provides a key marker for correlation with section 5 in core 10 of Hole 1202B (Appendix Fig. 8). 


\subsubsection{Cores $11(85.7$ - 90.07 mbsf $)$}

Core 11 is exclusively of hemipelagic mud with a visible silt-sand layer in section 2 (Appendix Fig. 9). Also found in the mud are bryozoans, echinoid spines and sponge spicules with the thin shells of pelecypods and well-preserved tests of benthic foraminifer Quinqueloculina. Pumice grains are observed in core CC.

\subsubsection{Core 12 (95.3 - 101.24 mbsf)}

Core 12 is composed of hemipelagic mud without any silt-sand layer (Appendix Fig. 10). There are rare mica flakes and woody remains with few planktic and indigenous benthic foraminifers.

\subsubsection{Core 13 (104.9 - 112.25 mbsf)}

The number of silt-sand layers increases remarkably from the lower part of Core 13 downward (Appendix Fig. 11). Sections 1 and 2 of Core 13 are hemipelagic muds in which a reworked Early-Middle Miocene agglutinated benthic foraminifer Gaudryina kokuseiensis (Chang 1960) occurs with very rare planktic foraminifers. Whitish very fine sand layers occur in sections 3, 4, 5 and core CC. Most of the very fine sand layers are rather thin (each $<0.1 \mathrm{~cm}$ ), however, grading features are observed in the base of the turbidite sand layers $(>0.5 \mathrm{~cm}$ thick).

\subsubsection{Core 14 (114.5 - 124.17 mbsf $)$}

Core 14 (Appendix Fig. 12) is characterized by occurrence of more sand layers than core 13 (Appendix Fig. 11). Most of sand layers are whitish owing to abundant quartz grains, white mica flakes and relatively rare fragments of slate chip and green schist. Foraminifers in hemipelagic mud are rare presumably due to a high sedimentation rate.

\subsubsection{Core 15 (124.1 - 133.76 mbsf)}

Core 15 contains hemipelagic muds intercalated with sand layers (Appendix Fig.13). Most of the sand layers are thin $(<0.1 \mathrm{~cm})$, but in some much thicker sand layers $(>0.5 \mathrm{~cm})$, the occurrences of basal erosion surface and grading features suggest turbidite sedimentation. Foraminifers are very rare in hemipelagic mud; however, rich planktic foraminifers are found in some turbidite layers presumably due to sorting.

\subsubsection{Core 16 (133.8 - 142.16 mbsf $)$}

Core 16 (Appendix Fig. 14) is composed of hemipelagic mud with rather common whitish very fine sand layers (10 - 20 whitish very fine sand layers in each $1.5 \mathrm{~m}$ section of core). Foraminifers are very rare in the hemipelagic mud of section 1, while mollusk, bryozoan fragments, echinoid spines and plates, and shallow-marine benthic foraminifers displaced from 
the continental shelf are very common in sand layers of section 2 . Some shallow-marine benthic foraminiferal tests even show black in color suggesting that they were eroded from the old strata of continental shelf environments. The coarse part of sediment $(>250 \mu \mathrm{m})$ is predominated by slate chips and bioclastics with rare schist and mica flakes.

\subsubsection{Core 17 (143.4 - 152.74 mbsf)}

The number and thickness of turbidite sand layers in Core 17 (Appendix Fig. 15) are more than those of Core 16 (Appendix Fig. 14). Basal erosion, grading and the presence of shallowmarine fauna indicate frequent turbidite sedimentation. Particles of several thicker sand layers $(>3 \mathrm{~cm})$ may reach fine to medium grain size. Coarse fraction $(>250 \mu \mathrm{m})$ of wash residues is predominated by slate chips and quartz with minor schist and mica flakes. Bioclastics of mollusks, bryozoans, echinoid spines, spongy spicules and benthic foraminifers derived from shallow-marine environments are very common. Planktic foraminifers are rather abundant in turbidite sand layers (e.g., 11-16 cm of section 4) presumably due to turbidite sorting. In contrast, in hemipelagic mud between turbidite sand layers both benthic and planktic foraminifer are rare (e.g., $58-63 \mathrm{~cm}$ of section 4 and $63.5-68 \mathrm{~cm}$ of section 6).

\subsubsection{Core 18 (153.0 - 161.75 mbsf $)$}

In Core 18 (Appendix Fig. 16) turbidite sand layers are common with abundant slate chips and displaced shallow-marine benthic foraminifers. In the turbidite sands, some foraminifers (both benthics and planktics) show black in color, suggesting they were reworked from the older strata of shelf deposits by turbidite erosions. However, foraminifers are very rare in hemipelagic mud (113-118 cm of section 1, $64-67 \mathrm{~cm}$ of section 4 and $63-68 \mathrm{~cm}$ of section 1), similar to what is observed in Core 17.

\subsubsection{Core 19 (162.7 - 171.17 mbsf)}

Core 19 is a hemipelagic mud dominant interval (Appendix Fig. 17). The number of sand layers in Core 19 is much less than in Cores 20 and 18. In these hemipelagic mud intervals, there are almost no displaced shallow-marine fauna. However, planktic and indigenous benthic foraminifers are also rare due to a high sedimentation rate.

\subsubsection{Core 20 (172.3 - 180.15 mbsf)}

Core 20 is characterized by the occurrence of turbidite sand layers, especially in the lower part (sections 3 - 5, Appendix Fig. 18). Basal erosion and grading feature from fine sand upward to silt and mud are commonly observed in each of the turbidite sand layers in which planktic foraminifers are abundant (e.g., 100 - $105 \mathrm{~cm}$ of section 4), but slate chips and mica flakes are rare. Bioclastics of echinoid spines and thin-shell bivalves are also rich in the turbidite sands. 


\subsubsection{Core 21 (172.3 - 180.15 mbsf)}

The number and thickness of sand layers increase form Core 21 to Core 31. Core 21 (Appendix Fig.19) is characterized by the occurrence of rich foraminifers tests, molluscan fragments and echinoid spines with abundant slate chips in thick sand layers $(>5 \mathrm{~cm}$, e.g., at $38-43 \mathrm{~cm}$ and $99-104 \mathrm{~cm}$ of section 2), while bioclastics, foraminifers and slate chips are rare, but mica flakes are abundant in the thin sand layers $(<5 \mathrm{~cm}$; e.g., at $21.2-25.6 \mathrm{~cm}$ of section 1; $103-108 \mathrm{~cm}$ and $125-130 \mathrm{~cm}$ of section 3). Distinct sorting effects caused by stronger turbidity flows would have resulted in the deposition of thick turbidite sand layers and the common occurrence of continent-derived slate chips and displaced shallow-marine bioclastics.

\subsubsection{Core 22 (191.7 - 199.73 mbsf $)$}

Grading features are commonly found in the turbidite sand layers of Core 22 (Appendix Fig. 20). Pumice grains and slate chips along with mica or schist flakes are found in $95-98 \mathrm{~cm}$ of section 1. In hemipelagic mud, continent-derived detritus and foraminifers are rare $(114-118 \mathrm{~cm}$ and $125-130 \mathrm{~cm}$ of section 3), while in turbidite sand layers (e.g., at $95-98 \mathrm{~cm}$ of section 1 and $32-36 \mathrm{~cm}$ of section 4) displaced benthic foraminifers, echinoid spines and molluscan fragments of shallow-marine fauna are common.

\subsubsection{Core 23 (201.3 - 208.5 mbsf)}

Core 23 contains many turbidite sand layers (Appendix Fig. 21). Some of them may reach $5-8 \mathrm{~cm}$ in thickness of which basal erosion and grading features are common. Most of the sand layers contain rich slate fragments. However, volcanic detritus and minerals with well-crystallized forms along with slate chips and quartz grains can be observed in the fine sands of section $5(108-110 \mathrm{~cm})$. Again as with the other cores, abundant shallow-marine benthic foraminifers, molluscan fragments and echinoid plates and spines can be found in the thick turbidite sands (138 - $143 \mathrm{~cm}$ of section 3), but they are rare in hemipelagic mud. Instead, indigenous benthic foraminifers are predominant in hemipelagic muds $(125-130 \mathrm{~cm}$ of section 3)

\subsubsection{Core 24 (210.9 - $219.13 \mathrm{mbsf})$}

Turbidite sand layers are commonly observed in Core 24 (Appendix Fig. 22). Volcanic detritus and minerals with well-developed crystal forms are found in $74-77 \mathrm{~cm}$, section 5 . Displaced shallow-marine benthic foraminifers, molluscan fragments and echinoid spines are abundant in the thick turbidite sand layers $(74-77 \mathrm{~cm}$, section 5).

\subsubsection{Core 25 (220.5 - 224.31 mbsf $)$}

A large part of Core 25 (Appendix Fig. 23) was not recovered by XBC coring probably due to the predominance of sand layers. Volcanic detritus can be found in $63-67 \mathrm{~cm}$ of section 
2 with very rare foraminifers. However, slate chips are abundant in the bottom of core CC.

\subsubsection{Core 26 (230.1 - $230.3 \mathrm{mbsf})$}

Core 26 was almost un-recovered (Appendix Fig. 24). Fine sands without foraminifers, but with abundant mica flakes and organic materials (grass?), can be observed in core CC.

\subsubsection{Core 27 (239.7 - $244.0 \mathrm{mbsf})$}

Core 27 is dominated by turbidite sand layers with normal grading structures and basal erosions (Appendix Fig. 25). Fauna are very rare in either the hemipelagic mud or turbidite sand layers. If there are benthic foraminifers, they are all shallow-marine species displaced from shallow-marine environments. However, organic materials and mica flakes are found in some fine sand layers (for example, $113-116 \mathrm{~cm}$, section 3).

\subsubsection{Core 28 (249.3 - 253.29 mbsf)}

Core 28 is composed predominantly of turbidite fine-grain sands with grading structures (Appendix Fig. 26). Each turbidite sand layer may reach $15 \mathrm{~cm}$ in thickness. Samples ranging from very fine sand to the silt part of the turbidite layer $(125-130 \mathrm{~cm}$, section2; $70-75 \mathrm{~cm}$ of section 3) contain very rich mica flakes and quartz grains, presumably derived from the Central Range of Taiwan. Organic materials, presumably plant, are abundant, suggesting the deposition site was not far from land. Microfossils foraminifers are very rare.

\subsubsection{Core 29 (nothing recovered)}

Nothing was recovered from Core 29.

\subsubsection{Core 30 (268.5 - $270.54 \mathrm{mbsf})$}

Only a small portion of Core 30 was recovered (Appendix Fig. 27). Core 30 is predominated by turbidite sands with grading structures. Foraminifers range from rare to common. Most of them were displaced from a shallow-marine environment. Mica flakes are very abundant.

\subsubsection{Core 31 (279.6 - 286.47 mbsf $)$}

The number of sand layers decreases from Core 31 (Appendix Fig. 28) downward. Although turbidite sand layers are fewer than in Cores 30 - 20, foraminifers in either hemipelagic mud ( 80 - $85 \mathrm{~cm}$, section 2) or turbidite sands ( 80 - $85 \mathrm{~cm}$ of section $3 ; 15.0-15.2 \mathrm{~cm}$ of section 5 ; $24-34 \mathrm{~cm}$ and $54-59 \mathrm{~cm}$ of section 6) are predominated by displaced shallow-marine species. Volcanic pumice and volcanic minerals with well-developed crystal forms can be observed in $80-85 \mathrm{~cm}$ of section 4 and $24-27 \mathrm{~cm}, 27-34 \mathrm{~cm}, 54-59 \mathrm{~cm}$ of section 6 . Slate chips are also found in some sand layers (e.g., at $80-85 \mathrm{~cm}$ of section 4 ). 


\subsubsection{Core 32 (287.8 - 295.15 mbsf $)$}

Core 32 (Appendix Fig. 29) contains more sand layers than in Core 31 (Appendix Fig. 28). Volcanic detritus are commonly found in the lower part (58- $69 \mathrm{~cm}$ of section 4 and $9-14$ $\mathrm{cm}, 114-121 \mathrm{~cm}$ of sections 5). Foraminifers are rare in the turbidite sand layers.

\subsubsection{Core 33 (297.4 - 305.93 mbsf)}

Core 33 is composed predominantly of hemipelagic mud with several very fine sand layers (Appendix Fig. 30). Detritus of coarse fraction are rare, but mica and slate are found. Foraminifers are almost barren in either hemipelagic mud or sand layers indicating a high sedimentation rate.

\subsubsection{Core 34 (307.0 - 315.57 mbsf)}

Core 34 consists predominantly of hemipelagic mud (Appendix Fig. 31). Turbidite sands with volcanic detritus can be found in $25-39 \mathrm{~cm}$ of section 2, $105-109 \mathrm{~cm}$ of section 3 , and $55-59 \mathrm{~cm}$ of section 4 . Foraminifers are rare but benthic species are all indigenous. Mica flakes can be found in the hemipelagic mud.

\subsubsection{Core 35 (316.6 - 325.29 mbsf)}

Core 35 is composed of hemipelagic mud with some silt to very fine sand layers (Appendix Fig. 32). Due to a high sedimentation rate, microfossils are all very rare in the sediments. Volcanic detritus are frequently found in sections 3, 4 and 5.

\subsubsection{Core 36 (326.2 - 335.9 mbsf $)$}

Core 36 (Appendix Fig. 33) is predominated by hemipelagic mud almost without any visible turbidite sedimentary features. Microfossils are very rare. A few mica flakes and slate chips can be found in the hemipelagic mud.

\subsubsection{Core 37 (335.9 - 344.27 mbsf) and Core 38 (345.6 - 354.72 mbsf)}

Sedimentological features of Core 37 (Appendix Fig. 34) and Core 38 are similar (Appendix Fig. 35). There are several very fine sand to silt layers. Mica flakes can be found in the coarse fraction $(>250 \mu \mathrm{m})$ and foraminifers are always very rare.

\subsubsection{Core 39 (355.30 - 363.27 mbsf)}

Core 39 is predominated by hemipelagic mud (Appendix Fig. 36). In these fine sediments both benthic and planktic foraminifers are very rare $(<20$ tests in 20 grams dry sediment), indicating a clear dilution effect due to a high sedimentation rate. Mica flakes are observed in several very fine sand to silt layers. 


\subsubsection{Core 40 (364.9 - 373.42 mbsf)}

Core 40 consists predominantly of hemipelagic mud (Appendix Fig. 37). No turbidite structure is observed. Volcanic detritus can be found in core CC (37 - $42 \mathrm{~cm})$, section $4(39-44 \mathrm{~cm})$ and $134-139 \mathrm{~cm}$ of section 2 . Foraminifers are very rare ( $<20$ tests in 20 grams of dry sediment), but they are all indigenous fauna.

\subsubsection{Core 41 (374.6 - 383. 37 mbsf)}

Core 41 is composed of hemipelagic muds with rare very thin $(<0.1 \mathrm{~cm})$, very fine sand to silt layers (Appendix Fig. 38). No turbidite structure can be observed. Volcanic detritus is found in the upper part (4-6 cm of section 1$)$ of the core. Microfossils are very rare $(<10$ tests in 20 grams of dry sediment).

\subsubsection{Core 42 (384.2 - 392.95 mbsf)}

Lithology of Core 42 (Appendix Fig. 38) and Core 41 (Appendix Fig. 39) is similar. However, foraminiferal tests in Core 42 are more abundant than in Core 41(>100 tests/20 g of dry sediment). These benthic foraminifers are all indigenous deep-water species.

\subsubsection{Core 43 (393.9 - 399.19 mbsf) and Core 44 (403.5 - $408.1 \mathrm{mbsf})$}

Both Core 43 (Appendix Fig. 40) and Core 44 (Appendix Fig. 41) are predominated by hemipelagic muds. Some mica and slate chips are found in the hemipelagic mud of both cores in which benthic foraminifers of well-preserved indigenous deep-marine species range from generally rare to common. No turbidite feature can be found.

\subsection{Sand Layer Ratio}

The Silt-Sand Layer Ratio (SLR) is defined as the ratio of the total thickness of silt-sand layers in each $1.5 \mathrm{~m}$ long section of core multiplied by $100 \%$. The results are listed in Table 1 and shown as Fig. 2. Based on the SLR data, Hole 1202D can be divided into 8 sections: Section $\mathrm{I}(0$ - $133 \mathrm{~m}$, Cores 0-15) is almost barren of silt-sand layers (SLR < 5\%); Section II's (133 - 167. 95 m, Cores 16-19) SLR fluctuates between 3 and $7 \%$; Section III's (167.95 - 199.12 m, Cores 1922) SLR increases to $45 \%$ in the upper part of Core 22; Section IV's (199.12 - $223.82 \mathrm{~m}$, Core 2225) SLR remains high (12 - $44 \%$; the highest SLR of $44.7 \%$ is at the lower part of Core 25). Between Sections III and IV, there is a lower SLR interval; Section V (223.82 - $280.35 \mathrm{~m}$, Cores $25-31$ ) is characterized by a very high SLR (> $29 \%$ with the highest SLR up to $90-100 \%$ in Cores 27 and 28) and the lowest sediment recovery in Hole 1202D. The SLR then decreases gradually down core from a high peak in Section V through moderate SLR values (4 - $27 \%$ ) in Section VI (280.35 - $310.75 \mathrm{~m}$, Cores 31-34) and Section VII (SLR: 4 - $10 \% ; 310.75-338.15 \mathrm{~m}$ in Cores 34-37) to a low SLR value (<3\%) in Section VIII (338.15 - $407.24 \mathrm{~m}$, Cores 37-44).

Using the age model constructed by Wei et al (2005), turbidite sand layer deposition in Hole 1202D is rare in the last $33 \mathrm{ka}$ or Stages 1-2 and the upper part of Stage 3 (Fig. 2). 
Table 1. Calculation of silt-sand layer ration (SLR) in Hole 1202D

\begin{tabular}{|c|c|c|c|c|c|c|}
\hline \multirow{2}{*}{ core } & \multirow{2}{*}{ section } & \multicolumn{2}{|c|}{ interval (mbsf) } & \multirow{2}{*}{$\begin{array}{c}\text { Silt-sand } \\
\text { thickness }(\mathrm{cm})\end{array}$} & \multirow{2}{*}{$\begin{array}{l}\text { SLR } \\
(\%)\end{array}$} & \multirow{2}{*}{ Remarks } \\
\hline & & top & bottom & & & \\
\hline 4 & 1 & 19.2 & 20.7 & 0 & 0.0 & A \\
\hline 4 & 2 & 20.7 & 22.2 & 0.6 & 0.4 & $\mathrm{~A}$ \\
\hline 4 & 3 & 22.2 & 23.7 & 3.5 & 2.4 & $A$ \\
\hline 4 & 4 & 23.7 & 25.2 & 3.5 & 2.4 & $\mathrm{~A}$ \\
\hline 4 & 5 & 25.2 & 26.7 & 4.1 & 3.0 & $\mathrm{~A}$ \\
\hline 4 & 6 & 26.7 & 28.2 & 2.6 & 1.7 & $\mathrm{~A}$ \\
\hline 4 & 7 & 28.2 & 29.09 & 3.5 & 4.1 & A \\
\hline 5 & 1 & 28.7 & 30.2 & 5.9 & 3.9 & $\mathrm{~A}$ \\
\hline 5 & 2 & 30.2 & 31.7 & 4.1 & 2.7 & $\mathrm{~A}$ \\
\hline 5 & 3 & 31.7 & 33.2 & 0 & 0.0 & $\mathrm{~A}$ \\
\hline 5 & 4 & 33.2 & 34.7 & 0.5 & 0.3 & $A$ \\
\hline 5 & 5 & 34.7 & 36.2 & 0.3 & 0.2 & $\mathrm{~A}$ \\
\hline 5 & 6 & 36.2 & 37.7 & 0.3 & 0.2 & $\mathrm{~A}$ \\
\hline 5 & 7 & 37.7 & 38.31 & 0.9 & 1.5 & $\mathrm{~A}$ \\
\hline 6 & 1 & 38.2 & 39.7 & 0.3 & 0.2 & A \\
\hline 6 & 2 & 39.7 & 41.2 & 0.1 & 0.1 & $\mathrm{~A}$ \\
\hline 6 & 3 & 41.2 & 42.7 & 0.9 & 0.6 & $\mathrm{~A}$ \\
\hline 6 & 4 & 42.7 & 44.2 & 1.8 & 1.2 & $\mathrm{~A}$ \\
\hline 6 & 5 & 44.2 & 45.7 & 1 & 0.7 & $\mathrm{~A}$ \\
\hline 6 & 6 & 45.7 & 47.2 & 0 & 0.0 & A \\
\hline 6 & 7 & 47.2 & 48.02 & 0.2 & 0.2 & $\mathrm{~A}$ \\
\hline 7 & 1 & 47.7 & 49.2 & 0.9 & 0.6 & $\mathrm{~A}$ \\
\hline 7 & 2 & 49.2 & 50.7 & 0.4 & 0.3 & $\mathrm{~A}$ \\
\hline 7 & 3 & 50.7 & 52.2 & 0.3 & 0.2 & $\mathrm{~A}$ \\
\hline 7 & 4 & 52.2 & 53.7 & 0.6 & 0.4 & $A$ \\
\hline
\end{tabular}


Table 1. Continued.

\begin{tabular}{|c|c|c|c|c|c|c|}
\hline 7 & 5 & 53.7 & 55.2 & 0.6 & 0.4 & A \\
\hline 7 & 6 & 55.2 & 56.7 & 0.6 & 0.4 & A \\
\hline 7 & 7 & 56.7 & 57.51 & 0 & 0.0 & A \\
\hline 8 & 1 & 57.2 & 58.7 & 0.6 & 0.4 & A \\
\hline 8 & 2 & 58.7 & 60.2 & 0.6 & 0.4 & A \\
\hline 8 & 3 & 60.2 & 61.7 & 0.1 & 0.1 & A \\
\hline 8 & 4 & 61.7 & 63.2 & 1 & 0.7 & A \\
\hline 8 & 5 & 63.2 & 64.7 & 0.2 & 0.1 & A \\
\hline 8 & 6 & 64.7 & 66.2 & 0.8 & 0.5 & A \\
\hline 8 & 7 & 66.2 & 67.11 & 0 & 0.0 & A \\
\hline 9 & 1 & 66.7 & 68.2 & 0 & 0.0 & A \\
\hline 9 & 2 & 68.2 & 69.7 & 0 & 0.0 & A \\
\hline 9 & 3 & 69.7 & 71.2 & 0 & 0.0 & A \\
\hline 9 & 4 & 71.2 & 72.7 & 0 & 0.0 & A \\
\hline 9 & 5 & 72.7 & 74.2 & 0 & 0.0 & A \\
\hline 9 & 6 & 74.2 & 75.7 & 2.5 & 1.7 & A \\
\hline 9 & 7 & 75.7 & 76.59 & 0.1 & 0.1 & A \\
\hline 10 & 1 & 76.2 & 77.7 & 0.5 & 0.3 & A \\
\hline 10 & 2 & 77.7 & 78.7 & 0 & 0.0 & A \\
\hline 10 & 3 & 78.7 & 79.53 & 3 & 3.6 & A \\
\hline 11 & 1 & 85.7 & 87.2 & 0 & 0.0 & A \\
\hline 11 & 2 & 87.2 & 88.7 & 0.1 & 0.1 & A \\
\hline 11 & 3 & 88.7 & 89.85 & 0 & 0.0 & A \\
\hline 12 & 1 & 95.3 & 96.8 & 0 & 0.0 & A \\
\hline 12 & 2 & 96.8 & 98.3 & 0 & 0.0 & A \\
\hline 12 & 3 & 98.3 & 99.8 & 0 & 0.0 & A \\
\hline 12 & 4 & 99.8 & 101.01 & 0 & 0.0 & A \\
\hline
\end{tabular}


Huang et al.

Table 1. Continued.

\begin{tabular}{|c|c|c|c|c|c|c|}
\hline 13 & 1 & 104.9 & 106.4 & 0.05 & 0.0 & A \\
\hline 13 & 2 & 106.4 & 107.9 & 0 & 0.0 & A \\
\hline 13 & 3 & 107.9 & 109.4 & 1.1 & 0.8 & A \\
\hline 13 & 4 & 109.4 & 110.9 & 1.2 & 0.8 & A \\
\hline 13 & 5 & 110.9 & 112.03 & 1 & 0.9 & A \\
\hline 14 & 1 & 114.5 & 116 & 3 & 2.0 & A \\
\hline 14 & 2 & 116 & 117.5 & 0.05 & 0.0 & A \\
\hline 14 & 3 & 117.5 & 119 & 1.7 & 1.2 & $\mathrm{~A}$ \\
\hline 14 & 4 & 119 & 120.5 & 3.1 & 2.1 & A \\
\hline 14 & 5 & 120.5 & 122 & 7.7 & 5.2 & A \\
\hline 14 & 6 & 122 & 123.5 & 2.3 & 1.7 & A \\
\hline 14 & 7 & 123.5 & 123.93 & 0.3 & 0.7 & A \\
\hline 15 & 1 & 124.1 & 125.6 & 1.3 & 0.9 & $\mathrm{~A}$ \\
\hline 15 & 2 & 125.6 & 127.1 & 2.4 & 1.6 & $\mathrm{~A}$ \\
\hline 15 & 3 & 127.1 & 128.6 & 1.9 & 1.3 & A \\
\hline 15 & 4 & 128.6 & 130.1 & 2.8 & 1.9 & A \\
\hline 15 & 5 & 130.1 & 131.6 & 1.2 & 0.8 & A \\
\hline 15 & 6 & 131.6 & 133.1 & 4.4 & 3.1 & A \\
\hline 15 & 7 & 133.1 & 133.57 & 0.5 & 1.1 & B \\
\hline 16 & 1 & 133.8 & 135.3 & 8.2 & 5.5 & B \\
\hline 16 & 2 & 135.3 & 136.8 & 6 & 4.4 & $\mathrm{~B}$ \\
\hline 16 & 3 & 136.8 & 138.3 & 9.5 & 7.0 & B \\
\hline 16 & 4 & 138.3 & 139.8 & 5 & 3.7 & $B$ \\
\hline 16 & 5 & 139.8 & 141.3 & 5.3 & 4.7 & B \\
\hline 16 & 6 & 141.3 & 141.94 & 3.2 & 6.0 & B \\
\hline 17 & 1 & 143.4 & 144.9 & 5.8 & 4.3 & B \\
\hline 17 & 2 & 144.9 & 146.4 & 10.2 & 7.3 & B \\
\hline
\end{tabular}


Table 1. Continued.

\begin{tabular}{|c|c|c|c|c|c|c|}
\hline 17 & 3 & 146.4 & 147.9 & 8.2 & 6.3 & B \\
\hline 17 & 4 & 147.9 & 149.4 & 7 & 4.9 & B \\
\hline 17 & 5 & 149.4 & 150.9 & 6.35 & 5.1 & B \\
\hline 17 & 6 & 150.9 & 152 & 4.5 & 4.5 & B \\
\hline 17 & 7 & 152 & 152.56 & 0.9 & 1.9 & B \\
\hline 18 & 1 & 153 & 154.5 & 0.3 & 0.2 & $B$ \\
\hline 18 & 2 & 154.5 & 155.88 & 7.8 & 6.5 & B \\
\hline 18 & 3 & 155.88 & 157.25 & 5.4 & 4.5 & B \\
\hline 18 & 4 & 157.25 & 158.75 & 8.1 & 5.7 & B \\
\hline 18 & 5 & 158.75 & 160.25 & 10.9 & 8.4 & B \\
\hline 18 & 6 & 160.25 & 161.54 & 2.8 & 2.2 & B \\
\hline 19 & 1 & 162.7 & 164,2 & 2 & 1.5 & B \\
\hline 19 & 2 & 164.2 & 165.7 & 0.5 & 0.4 & $B$ \\
\hline 19 & 3 & 165.7 & 167.2 & 0.3 & 0.2 & B \\
\hline 19 & 4 & 167.2 & 168.7 & 0.9 & 0.6 & $\mathrm{C}$ \\
\hline 19 & 5 & 168.7 & 170.2 & 3.9 & 3.1 & $\mathrm{C}$ \\
\hline 19 & 6 & 170.2 & 170.97 & 4.3 & 6.2 & $\mathrm{C}$ \\
\hline 20 & 1 & 172.3 & 173.8 & 2.9 & 2.1 & C \\
\hline 20 & 2 & 173.8 & 175.3 & 13.8 & 9.8 & C \\
\hline 20 & 3 & 175.3 & 176.8 & 7.4 & 5.7 & $\mathrm{C}$ \\
\hline 20 & 4 & 176.8 & 178.3 & 23.7 & 16.9 & C \\
\hline 20 & 5 & 178.3 & 179.68 & 14.7 & 11.8 & C \\
\hline 21 & 1 & 182 & 183.5 & 20.4 & 14.8 & C \\
\hline 21 & 2 & 183.5 & 185 & 50.6 & 35.6 & C \\
\hline 21 & 3 & 185 & 186.5 & 32.1 & 24.8 & C \\
\hline 21 & 4 & 186.5 & 187.6 & 21.3 & 20.9 & $\mathrm{C}$ \\
\hline 21 & 5 & 187.6 & 188.25 & 18.5 & 34.6 & C \\
\hline
\end{tabular}


Huang et al.

Table 1. Continued.

\begin{tabular}{|c|c|c|c|c|c|c|}
\hline 22 & 1 & 191.7 & 193.2 & 60.3 & 44.3 & $\mathrm{C}$ \\
\hline 22 & 2 & 193.2 & 194.7 & 63.5 & 45.0 & C \\
\hline 22 & 3 & 194.7 & 196.2 & 19.3 & 14.6 & $\mathrm{C}$ \\
\hline 22 & 4 & 196.2 & 197.7 & 34.8 & 25.5 & $\mathrm{C}$ \\
\hline 22 & 5 & 197.7 & 198.9 & 13 & 12.3 & $\mathrm{C}$ \\
\hline 22 & 6 & 198.9 & 199.33 & 2.4 & 5.6 & $\mathrm{D}$ \\
\hline 23 & 1 & 201.3 & 202.8 & 13.6 & 9.9 & $\mathrm{D}$ \\
\hline 23 & 2 & 202.8 & 204.3 & 11.4 & 8.5 & $\mathrm{D}$ \\
\hline 23 & 3 & 204.3 & 205.8 & 26.9 & 20.2 & $\mathrm{D}$ \\
\hline 23 & 4 & 205.8 & 206.82 & 9.8 & 12.4 & $\mathrm{D}$ \\
\hline 23 & 5 & 206.82 & 208.08 & 20.8 & 19.0 & $D$ \\
\hline 24 & 1 & 210.9 & 212.4 & 22.9 & 16.8 & $\mathrm{D}$ \\
\hline 24 & 2 & 212.4 & 213.9 & 25 & 17.9 & D \\
\hline 24 & 3 & 213.9 & 215.4 & 30.1 & 22.9 & $\mathrm{D}$ \\
\hline 24 & 4 & 215.4 & 216.9 & 36.9 & 26.2 & $\mathrm{D}$ \\
\hline 24 & 5 & 216.9 & 217.93 & 15 & 16.3 & $\mathrm{D}$ \\
\hline 24 & 6 & 217.93 & 218.54 & 10.4 & 19.6 & D \\
\hline 25 & 1 & 220.5 & 222 & 42.7 & 31.6 & $\mathrm{D}$ \\
\hline 25 & 2 & 222 & 223.5 & 58.4 & 44.8 & $\mathrm{D}$ \\
\hline 25 & 3 & 223.5 & 224.13 & 3.1 & 5.8 & $\mathrm{D}$ \\
\hline 27 & 1 & 239.7 & 241.2 & 78.6 & 62.4 & $E$ \\
\hline 27 & 2 & 241.2 & 242.7 & 40.3 & 29.8 & $\mathrm{E}$ \\
\hline 27 & 3 & 242.7 & 243.87 & 71.6 & 72.0 & $E$ \\
\hline 28 & 1 & 249.3 & 250.8 & 145.5 & 100.0 & $\mathrm{E}$ \\
\hline 28 & 2 & 250.8 & 252.3 & 130.9 & 92.2 & $\mathrm{E}$ \\
\hline 28 & 3 & 252.3 & 253.15 & 41.3 & 49.0 & $E$ \\
\hline 30 & 1 & 268.5 & 270 & 68.6 & 51.6 & $E$ \\
\hline
\end{tabular}


Table 1. Continued.

\begin{tabular}{|c|c|c|c|c|c|c|}
\hline 30 & 2 & 270 & 270.35 & 22 & 62.9 & $\mathrm{E}$ \\
\hline 31 & 1 & 278.1 & 279.6 & 0 & 0.0 & $\mathrm{E}$ \\
\hline 31 & 2 & 279.6 & 281.1 & 0 & 0.0 & $E$ \\
\hline 31 & 3 & 281.1 & 282.6 & 6.6 & 4.4 & $F$ \\
\hline 31 & 4 & 282.6 & 284.1 & 19 & 12.7 & $\mathrm{~F}$ \\
\hline 31 & 5 & 284.1 & 285.37 & 11.8 & 9.3 & $\mathrm{~F}$ \\
\hline 31 & 6 & 285.37 & 286 & 15.2 & 27.6 & $\mathrm{~F}$ \\
\hline 32 & 1 & 287.8 & 289.3 & 0.2 & 0.1 & $\mathrm{~F}$ \\
\hline 32 & 2 & 289.3 & 290.8 & 26.8 & 19.1 & F \\
\hline 32 & 3 & 290.8 & 292.26 & 23.5 & 18.6 & $\mathrm{~F}$ \\
\hline 32 & 4 & 292.26 & 293.76 & 35.4 & 25.7 & $\mathrm{~F}$ \\
\hline 32 & 5 & 293.76 & 295.01 & 22.5 & 20.7 & $F$ \\
\hline 33 & 1 & 297.4 & 298.9 & 3.9 & 2.9 & $\mathrm{~F}$ \\
\hline 33 & 2 & 298.9 & 300.4 & 5.7 & 4.2 & $\mathrm{~F}$ \\
\hline 33 & 3 & 300.4 & 301.82 & 9.7 & 8.1 & $F$ \\
\hline 33 & 4 & 301.82 & 303.32 & 0.6 & 0.5 & $\mathrm{~F}$ \\
\hline 33 & 5 & 303.32 & 304.47 & 3.5 & 3.5 & $F$ \\
\hline 33 & 6 & 304.47 & 305.67 & 0.2 & 0.2 & $\mathrm{~F}$ \\
\hline 34 & 1 & 307 & 308.5 & 10.8 & 8.0 & $\mathrm{~F}$ \\
\hline 34 & 2 & 308.5 & 310 & 0.2 & 0.1 & $\mathrm{~F}$ \\
\hline 34 & 3 & 310 & 311.5 & 0 & 0.0 & $\mathrm{G}$ \\
\hline 34 & 4 & 311.5 & 313 & 2.4 & 1.7 & $\mathrm{G}$ \\
\hline 34 & 5 & 313 & 314.5 & 3.9 & 2.8 & $\mathrm{G}$ \\
\hline 34 & 6 & 314.5 & 315.42 & 0.4 & 0.5 & $\mathrm{G}$ \\
\hline 35 & 1 & 316.6 & 318.1 & 4.9 & 3.7 & G \\
\hline 35 & 2 & 318.1 & 319.6 & 0.95 & 0.7 & $\mathrm{G}$ \\
\hline 35 & 3 & 319.6 & 321.1 & 0.4 & 0.3 & $\mathrm{G}$ \\
\hline
\end{tabular}


Huang et al.

Table 1. Continued.

\begin{tabular}{|c|c|c|c|c|c|c|}
\hline 35 & 4 & 321.1 & 322.41 & 4.2 & 3.5 & $\mathrm{G}$ \\
\hline 35 & 5 & 322.41 & 323.93 & 5.8 & 4.2 & $\mathrm{G}$ \\
\hline 35 & 6 & 323.93 & 325.29 & 0.5 & 0.4 & $\mathrm{G}$ \\
\hline 36 & 1 & 326.2 & 327.7 & 0.3 & 0.2 & $\mathrm{G}$ \\
\hline 36 & 2 & 327.7 & 329.2 & 4.2 & 3.1 & $\mathrm{G}$ \\
\hline 36 & 3 & 329.2 & 330.7 & 2.6 & 2.0 & $\mathrm{G}$ \\
\hline 36 & 4 & 330.7 & 332.2 & 4.8 & 3.5 & $\mathrm{G}$ \\
\hline 36 & 5 & 332.2 & 333.54 & 10.4 & 8.7 & $\mathrm{G}$ \\
\hline 36 & 6 & 333.54 & 334.57 & 9.75 & 10.5 & G \\
\hline 37 & 1 & 335.9 & 337.4 & 2.2 & 1.5 & $\mathrm{G}$ \\
\hline 37 & 2 & 337.4 & 338.9 & 1.9 & 1.3 & $\mathrm{H}$ \\
\hline 37 & 3 & 338.9 & 340.4 & 1.4 & 0.9 & $\mathrm{H}$ \\
\hline 37 & 4 & 340.4 & 341.63 & 0.5 & 0.4 & $\mathrm{H}$ \\
\hline 37 & 5 & 341.63 & 342.63 & 1.1 & 1.1 & $\mathrm{H}$ \\
\hline 37 & 6 & 342.63 & 343.35 & 0.6 & 0.8 & $\mathrm{H}$ \\
\hline 38 & 1 & 345.6 & 347.1 & 1.9 & 1.3 & $\mathrm{H}$ \\
\hline 38 & 2 & 347.1 & 348.6 & 1.6 & 1.1 & $\mathrm{H}$ \\
\hline 38 & 3 & 348.6 & 350.1 & 2.4 & 1.6 & $\mathrm{H}$ \\
\hline 38 & 4 & 350.1 & 351.6 & 2 & 1.3 & $\mathrm{H}$ \\
\hline 38 & 5 & 351.6 & 353.1 & 0.6 & 0.4 & $\mathrm{H}$ \\
\hline 38 & 6 & 353.1 & 354.15 & 0.1 & 0.1 & $\mathrm{H}$ \\
\hline 39 & 1 & 355.3 & 356.8 & 0.8 & 0.5 & $\mathrm{H}$ \\
\hline 39 & 2 & 356.8 & 358.3 & 1.4 & 0.9 & $\mathrm{H}$ \\
\hline 39 & 3 & 358.3 & 359.8 & 1.8 & 1.2 & $\mathrm{H}$ \\
\hline 39 & 4 & 359.8 & 361.18 & 0.9 & 0.7 & $\mathrm{H}$ \\
\hline 39 & 5 & 361.18 & 362.08 & 0.2 & 0.2 & $\mathrm{H}$ \\
\hline 39 & 6 & 362.08 & 363.27 & 0.3 & 0.3 & $\mathrm{H}$ \\
\hline
\end{tabular}


Table 1. Continued.

\begin{tabular}{|l|l|l|l|l|l|l|}
\hline 40 & 1 & 364.9 & 366.4 & 2.6 & 1.7 & $\mathrm{H}$ \\
\hline 40 & 2 & 366.4 & 367.9 & 1.7 & 1.1 & $\mathrm{H}$ \\
\hline 40 & 3 & 367.9 & 369.4 & 1.3 & 0.9 & $\mathrm{H}$ \\
\hline 40 & 4 & 369.4 & 370.9 & 3.8 & 2.5 & $\mathrm{H}$ \\
\hline 40 & 5 & 370.9 & 372.36 & 1.7 & 1.2 & $\mathrm{H}$ \\
\hline 41 & 1 & 374.6 & 376.1 & 1.7 & 1.1 & $\mathrm{H}$ \\
\hline 41 & 2 & 376.1 & 377.6 & 1.4 & 0.9 & $\mathrm{H}$ \\
\hline 41 & 3 & 377.6 & 379.1 & 1.5 & 1.0 & $\mathrm{H}$ \\
\hline 41 & 4 & 379.1 & 380.6 & 0.4 & 0.3 & $\mathrm{H}$ \\
\hline 41 & 5 & 380.6 & 381.99 & 1.3 & 0.9 & $\mathrm{H}$ \\
\hline 41 & 6 & 381.99 & 382.99 & 1 & 1.0 & $\mathrm{H}$ \\
\hline 42 & 1 & 384.2 & 385.7 & 0.4 & 0.3 & $\mathrm{H}$ \\
\hline 42 & 2 & 385.7 & 387.2 & 0.6 & 0.4 & $\mathrm{H}$ \\
\hline 42 & 3 & 387.2 & 388.7 & 0.9 & 0.6 & $\mathrm{H}$ \\
\hline 42 & 4 & 388.7 & 390.2 & 1.7 & 1.1 & $\mathrm{H}$ \\
\hline 42 & 5 & 390.2 & 391.7 & 0.4 & 0.3 & $\mathrm{H}$ \\
\hline 42 & 6 & 391.7 & 392.7 & 0.2 & 0.2 & $\mathrm{H}$ \\
\hline 43 & 1 & 393.9 & 395.4 & 0.6 & 0.4 & $\mathrm{H}$ \\
\hline 43 & 2 & 395.4 & 396.9 & 1.1 & 0.7 & $\mathrm{H}$ \\
\hline 43 & 3 & 396.9 & 398.4 & 0.9 & 0.6 & $\mathrm{H}$ \\
\hline 43 & 4 & 398.4 & 398.85 & 0.5 & 1.1 & $\mathrm{H}$ \\
\hline 44 & 1 & 403.5 & 405 & 1.3 & 0.9 & $\mathrm{H}$ \\
\hline 44 & 2 & 405 & 406.5 & 1 & 0.7 & $\mathrm{H}$ \\
\hline 44 & 3 & 406.5 & 407.97 & 1.15 & 0.8 & $\mathrm{H}$ \\
\hline
\end{tabular}




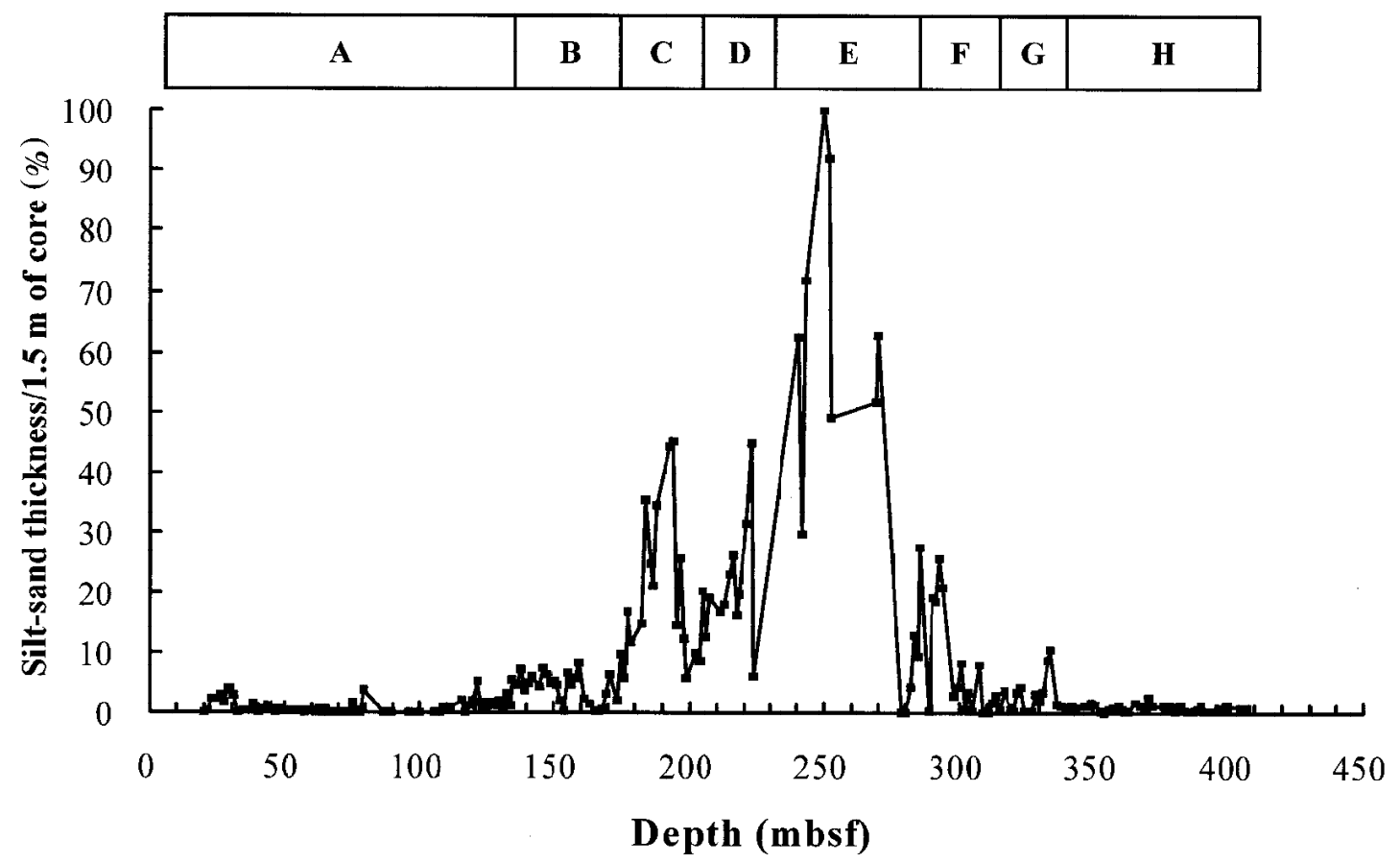

Fig. 2. Ratio of silt-sand layer thickness (SLR) in each $1.5 \mathrm{~m}$ length of core, Hole 1202D. Based on this SLR ratio, the core can be divided into 8 sections (A to $\mathrm{H})$.

However, it became very common during Stages 3 and 4 .

\subsection{Composition of Detritus in the Coarse Fraction $(>250 \mu \mathrm{m})$}

Terrigenous detritus in washing residues (coarse fraction $>250 \mu \mathrm{m}$ ) of Hole 1202D are determined under stereo-microscope (X60) and the results are listed in Table 2. Terrigenous detritus in Hole 1202D are primarily composed of slate chips, volcanics, mica flakes and quartz grains (Fig. 3). We put volcanic fragments and volcanic minerals with distinct crystal forms together as volcanics in Table 2. Both sedimentary and volcanic origins of quartz grains were found; however, it is difficult to identify them precisely under a stereo-microscope. Consequently they have been listed together in Table 2, and the significance is not considered. However, elimination of quartz grains ought not interfere with conclusions as to sediment sources as the remaining three components (slate, mica and volcanics) are all adequately represented to reflect sediment provenances. Slate fragments are commonly found in turbidite dominant intervals $(160-280 \mathrm{~m})$, while mica flakes can be found in fine sediments throughout the core. Volcanic detritus appear in the middle and lower parts of the core. Slate and mica are 
frequently found in study samples, but volcanic detritus usually appear alone (Fig. 3). Occurrences of these major components of detritus suggest that the materials were primarily derived from the Central Range of Taiwan where the Miocene deep-marine slates of accretionary prism overlay the Early Tertiary - Paleozoic metamorphic basement of the underthrust Eurasian continent (Fig. 4) in northern Taiwan (Huang et al. 1977; 2000). Volcanics could represent eruptions in the active-extension back-arc basin of the southern Okinawa Trough off NE Taiwan or secondary erosions from the submarine volcanic mountains in the trough. The bathymetric map of the southern Okinawa Trough shows there are two submarine canyons (A and C in Fig. 1). Between these two submarine channels, there is a concave depression (B in Fig. 1) due to slope failure. The northern submarine canyon (A in Fig. 1) is active today and has a point-source following the onland Lanyang River which develops from the accretionary wedge slate belt in the western part of Central Range of northern Taiwan (Fig. 1). The southern submarine canyon (C in Fig. 1) does not have an active source today. The canyon $\mathrm{C}$ can be traced to the continental shelf $(150 \mathrm{~m}$ in depth). Since there is no major river except the Lanyang River north of $24^{\circ} 30^{\prime} \mathrm{N}$, the submarine canyon C could represent a paleo-channel of this river during the last glacial time before channel migration in the Holocene due to sea-level rise. Here, the sediments eroded from the Central Range were transported to the site of Hole 1202D either via submarine channel transportation or by slope failures before finally being deposited in the southern Okinawa Trough.

In addition, shallow-marine fossils including benthic foraminifers, echinoids, bryozoans and mollusks were also transported into deep-marine environments (Table 2). The fossil assemblages could have been deposited in shallow-shelf and then transported to the deep depositional site via submarine channel erosion or by slope failures due to frequent earthquakes induced by plate convergence/collision and extension of the southwestern Okinawa Trough off NE Taiwan (Kao et al. 1998; Huh et al. 2004).

\section{CONCLUSIONS}

The sediments of ODP Site 1202, Leg 195, in the southern Okinawa Trough consist of hemipelagic mud in the upper $100 \mathrm{~m}$ (Stages 1-2). Silt-sand layers occur from $133 \mathrm{mbsf}$ (Stage 3) down core to 337 mbsf (Stage 4). The Silt-Sand Layer Ratio (SLR) increases from $<10 \%$ in $133-167 \mathrm{~m}$ to more than $50 \%$ in $223-279 \mathrm{~m}$, then decreases to less than $10 \%$ in $310-337 \mathrm{~m}$ and less than $3 \%$ in $337-407 \mathrm{~m}$ (Stage 4), suggesting fine grained turbidite depositions were very active in Stages 3 and 4. Detritus in wash residues $(>250 \mu \mathrm{m})$ of Hole 1202D are predominated by slate fragments, quartz grains, mica flakes and volcanic detritus. Slate fragments, quartz grains and mica flakes are primarily derived from the accretionary prism of the Central Range in northern Taiwan where the Miocene slates overlay the Early Tertiary - Paleozoic schists and marbles of underthrust Eurasian continent. Occurrences of volcanics could represent submarine volcanic activity in the active-opening Okinawa Trough back-arc basin off NE Taiwan. Shallow-marine fossils including benthic foraminifers, echinoids, bryozoans and mollusks were also transported into deep-marine environments. The fossil assemblages could have been deposited in the shallow-shelf and then transported to the deep depositional site via 
Table 2. Occurrence of detritus and bioclastics in coarse fraction (> $250 \mu \mathrm{m})$ of wash residues of Hole 1202D, Leg 195. X: barren; R: rare; A: Abundant.

\begin{tabular}{|c|c|c|c|c|c|c|c|c|c|c|c|c|c|}
\hline \multirow{2}{*}{$\begin{array}{c}\text { core } \\
012 \mathrm{X} \\
\end{array}$} & \multirow{2}{*}{\begin{tabular}{|l} 
section \\
$01 \mathrm{~W}$
\end{tabular}} & \multicolumn{2}{|c|}{ Depth (mbsf) } & \multirow{2}{*}{$\frac{\text { volcanics }}{0}$} & \multirow{2}{*}{\begin{tabular}{|c|} 
slates \\
11 \\
\end{tabular}} & \multirow{2}{*}{\begin{tabular}{|c|} 
metamorphics \\
5 \\
\end{tabular}} & \multirow{2}{*}{\begin{tabular}{|c|} 
total \\
16 \\
\end{tabular}} & \multirow{2}{*}{$\begin{array}{c}\text { Yoleanics } \\
\% \\
0\end{array}$} & \multirow{2}{*}{$\begin{array}{c}\text { Slates } \\
(\%)\end{array}$} & \multirow{2}{*}{\begin{tabular}{|c|} 
Metamorphiss \\
31.3 \\
\end{tabular}} & \multirow{2}{*}{\begin{tabular}{|c|} 
Mollusks \\
$X$ \\
\end{tabular}} & \multirow{2}{*}{$\begin{array}{c}\text { Echinoderms } \\
X \\
\end{array}$} & \multirow{2}{*}{\begin{tabular}{|c} 
Spongy \\
$\mathrm{X}$ \\
\end{tabular}} \\
\hline & & 96.55 & 96.6 & & & & & & & & & & \\
\hline $014 \mathrm{X}$ & $05 \mathrm{~W}$ & 121.19 & 121.26 & 14 & 7 & 56 & 77 & 18.2 & 9.1 & 72.7 & A & $\mathrm{X}$ & A \\
\hline $016 \mathrm{X}$ & $01 \mathrm{~W}$ & 134.81 & 134.84 & 0 & 27 & 0 & 27 & 0 & 100 & 0 & $x$ & $x$ & $x$ \\
\hline $016 \mathrm{X}$ & $02 \mathrm{~W}$ & 135.7 & 135.73 & 0 & 84 & 10 & 94 & 0 & 89.4 & 10.6 & A & $\mathrm{R}$ & $\mathrm{R}$ \\
\hline $016 \mathrm{X}$ & $04 \mathrm{~W}$ & 138.93 & 138.97 & 3 & 8 & 7 & 18 & 16.7 & 44.4 & 38.9 & $\mathrm{R}$ & $X$ & $x$ \\
\hline $016 \mathrm{X}$ & $04 \mathrm{~W}$ & 139.55 & 139.6 & 0 & 32 & 10 & 42 & 0 & 76.2 & 23.8 & A & A & A \\
\hline $016 \mathrm{X}$ & $06 \mathrm{~W}$ & 141.7 & 141.74 & 0 & 46 & 3 & 49 & 0 & 93.9 & 6.1 & $\mathrm{X}$ & $X$ & $X$ \\
\hline $017 \mathrm{X}$ & $01 \mathrm{~W}$ & 144.4 & 144.44 & 338 & 483 & 6 & 827 & 40.9 & 58.4 & 0.7 & $X$ & $X$ & $X$ \\
\hline $017 \mathrm{X}$ & $04 \mathrm{~W}$ & 148.01 & 148.06 & 0 & 43 & 7 & 50 & 0 & 86 & 14 & A & A & $\mathrm{X}$ \\
\hline $017 \mathrm{X}$ & $06 \mathrm{~W}$ & 151.54 & 151.58 & 64 & 1 & 0 & 65 & 98.5 & 1.5 & 0 & $X$ & $X$ & $X$ \\
\hline $018 \mathrm{X}$ & $01 \mathrm{~W}$ & 154.13 & 154.18 & 0 & 8 & 0 & 8 & 0 & 100 & 0 & $X$ & $X$ & X \\
\hline $018 \mathrm{X}$ & $04 \mathrm{~W}$ & 158.63 & 158.67 & 3 & 3 & 13 & 19 & 15.8 & 15.8 & 68.4 & A & A & A \\
\hline $018 \mathrm{X}$ & $05 \mathrm{~W}$ & 159.53 & 159.55 & 6 & 310 & 13 & 329 & 1.8 & 94.2 & 4 & $\mathrm{R}$ & $\mathrm{R}$ & $\mathrm{R}$ \\
\hline $020 \mathrm{X}$ & $02 \mathrm{~W}$ & 174.21 & 174.25 & 11 & 0 & 14 & 25 & 44 & 0 & 56 & A & A & A \\
\hline $020 \mathrm{X}$ & $03 \mathrm{~W}$ & 176.55 & 176.6 & 0 & 8 & 36 & 44 & 0 & 18.2 & 81.8 & $\mathrm{R}$ & $X$ & $\mathrm{X}$ \\
\hline $020 \mathrm{X}$ & $04 \mathrm{~W}$ & 177.8 & 177.85 & 0 & 18 & 46 & 54 & 0 & 28.1 & 71.9 & A & A & A \\
\hline $021 \mathrm{X}$ & $01 \mathrm{~W}$ & 182.21 & 182.26 & 0 & 17 & 2 & 19 & 0 & 89.5 & 10.5 & A & A & $\mathrm{x}$ \\
\hline $021 X$ & $02 \mathrm{~W}$ & 183.88 & 183.93 & 5 & 48 & 15 & 68 & 7.4 & 70.6 & 22.1 & $\mathrm{X}$ & $\mathrm{X}$ & X \\
\hline $021 \mathrm{X}$ & $02 \mathrm{~W}$ & 184.49 & 184.54 & 0 & 125 & 14 & 139 & 0 & 89.9 & 10.1 & $\mathrm{X}$ & $X$ & $\mathrm{X}$ \\
\hline $021 \mathrm{X}$ & $03 \mathrm{~W}$ & 186.03 & 186.08 & 0 & 0 & 59 & 59 & 0 & 0 & 100 & $X$ & $\mathrm{R}$ & $\mathrm{R}$ \\
\hline $021 x$ & $04 \mathrm{~W}$ & 186.95 & 186.97 & 0 & 0 & 12 & 12 & 0 & 0 & 100 & $x$ & $x$ & $x$ \\
\hline $021 X$ & $05 \mathrm{~W}$ & 187.73 & 187.76 & 0 & 1 & 135 & 136 & 0 & 0.7 & 99.3 & $\mathrm{X}$ & $\mathrm{R}$ & X \\
\hline $022 \mathrm{X}$ & $01 \mathrm{~W}$ & 192.65 & 192.68 & 24 & 10 & 9 & 43 & 55.8 & 23.3 & 20.9 & A & A & A \\
\hline $022 \mathrm{X}$ & $04 \mathrm{~W}$ & 196.52 & 196.56 & 0 & 0 & 14 & 14 & 0 & 0 & 100 & $\mathrm{X}$ & $X$ & $x$ \\
\hline $023 X$ & $03 \mathrm{~W}$ & 205.55 & 205.6 & 0 & 1 & 83 & 84 & 0 & 1.2 & 98.8 & A & A & A \\
\hline
\end{tabular}


Table 2. Continued.

\begin{tabular}{|c|c|c|c|c|c|c|c|c|c|c|c|c|c|}
\hline $023 X$ & $03 \mathrm{~W}$ & 205.7 & 205.75 & 0 & 69 & 22 & 91 & 0 & 75.8 & 24.2 & A & A & $X$ \\
\hline $023 \mathrm{X}$ & $05 W$ & 207.9 & 207.92 & 45 & 41 & 0 & 86 & 52.3 & 47.7 & 0 & A & $X$ & $X$ \\
\hline $024 \mathrm{X}$ & $01 \mathrm{~W}$ & 212.04 & 212.08 & 42 & 3 & 0 & 45 & 93.3 & 6.7 & 0 & $\mathrm{R}$ & $X$ & $\mathrm{X}$ \\
\hline $024 \mathrm{X}$ & $01 \mathrm{~W}$ & 212.13 & 212.15 & 4 & 17 & 58 & 79 & 5.1 & 21.5 & 73.4 & $\mathrm{X}$ & $X$ & $\mathrm{R}$ \\
\hline $024 \mathrm{X}$ & $03 \mathrm{~W}$ & 215.03 & 215.06 & 6 & 29 & 1 & 36 & 16.7 & 80.6 & 28 & $\mathrm{R}$ & $X$ & $X$ \\
\hline $024 \mathrm{X}$ & $03 \mathrm{~W}$ & 215.07 & 215.09 & 92 & 198 & 37 & 327 & 28.1 & 60.6 & 11.3 & $x$ & $x$ & $\mathrm{X}$ \\
\hline $024 \mathrm{X}$ & $03 \mathrm{~W}$ & 215.15 & 215.2 & 2 & 8 & 6 & 16 & 12.5 & 50 & 37.5 & $\mathrm{R}$ & $X$ & $\mathrm{R}$ \\
\hline $024 \mathrm{X}$ & $05 \mathrm{~W}$ & 217.64 & 217.67 & 122 & 247 & 0 & 369 & 33.1 & 66.9 & 0 & A & $\mathrm{A}$ & $\mathrm{X}$ \\
\hline $025 \mathrm{X}$ & $02 \mathrm{~W}$ & 222.63 & 222.65 & 41. & 0 & 8 & 49 & 83.7 & 0 & 16.3 & $X$ & $x$ & $\mathrm{X}$ \\
\hline $026 \mathrm{X}$ & $\mathrm{CCW}$ & 230.16 & 230.2 & 0 & 0 & 139 & 139 & 0 & 0 & 100 & $X$ & $\mathrm{X}$ & $X$ \\
\hline $027 \mathrm{X}$ & $01 \mathrm{~W}$ & 239.84 & 239.88 & 8 & 20 & 341 & 369 & 2.2 & 5.4 & 92.4 & A & $X$ & $X$ \\
\hline $027 \mathrm{X}$ & $01 \mathrm{~W}$ & 240.84 & 240.88 & 5 & 5 & 9 & 19 & 26.3 & 26.3 & 47.4 & $\mathrm{X}$ & $X$ & $X$ \\
\hline $027 \mathrm{X}$ & $02 \mathrm{~W}$ & 241.86 & 241.91 & 0 & 0 & 9 & 9 & 0 & 0 & 100 & $X$ & $X$ & $X$ \\
\hline $027 \mathrm{X}$ & $03 \mathrm{~W}$ & 243.36 & 243.4 & 0 & 0 & 8 & 8 & 0 & 0 & 100 & $\mathrm{X}$ & $X$ & $\mathrm{X}$ \\
\hline $027 \mathrm{X}$ & $03 \mathrm{~W}$ & 243.74 & 243.78 & 0 & 0 & 10 & 10 & 0 & 0 & 100 & $\mathrm{X}$ & $X$ & $X$ \\
\hline $027 \mathrm{X}$ & $03 \mathrm{~W}$ & 243.84 & 243.86 & 0 & 0 & 275 & 275 & 0 & 0 & 100 & $\mathrm{~A}$ & $\mathrm{X}$ & $\mathrm{X}$ \\
\hline $028 \mathrm{X}$ & $02 \mathrm{~W}$ & 252.05 & 252.1 & 0 & 0 & 100 & 100 & 0 & 0 & 100 & $x$ & $X$ & $X$ \\
\hline $028 \mathrm{X}$ & $03 \mathrm{~W}$ & 253 & 253.05 & 4 & 4 & 766 & 774 & 0.5 & 0.5 & 99 & A & A & A \\
\hline $030 \mathrm{X}$ & $01 \mathrm{~W}$ & 269.09 & 269.13 & 15 & 0 & 401 & 416 & 3.6 & 0 & 96.4 & A & $\mathrm{A}$ & A \\
\hline $030 \mathrm{X}$ & $02 \mathrm{~W}$ & 270.3 & 270.34 & 23 & 0 & 364 & 387 & 5.9 & 0 & 94.1 & $\mathrm{~A}$ & $\mathrm{~A}$ & A \\
\hline $030 \mathrm{x}$ & $\mathrm{CCW}$ & 270.43 & 270.49 & 7 & 0 & 876 & 883 & 0.8 & 0 & 99.2 & $\mathrm{R}$ & $X$ & $X$ \\
\hline $031 \mathrm{X}$ & $02 \mathrm{~W}$ & 280.4 & 280.45 & 6 & 0 & 20 & 26 & 23.1 & 0 & 76.9 & $\mathrm{R}$ & $\mathrm{X}$ & $\mathrm{R}$ \\
\hline $031 \mathrm{X}$ & $04 \mathrm{~W}$ & 283.3 & 283.35 & 13 & 0 & 127 & 140 & 9.3 & 0 & 90.7 & $\mathrm{R}$ & $\mathrm{R}$ & $\mathrm{R}$ \\
\hline $031 x$ & $04 \mathrm{~W}$ & 283.4 & 283.45 & 232 & 18 & 1 & 251 & 92.4 & 7.2 & 0.4 & $\mathrm{~A}$ & $\mathrm{R}$ & $X$ \\
\hline $031 \mathrm{X}$ & $05 \mathrm{~W}$ & 284.25 & 284.25 & 2 & 0 & 9 & 11 & 18.2 & 0 & 81.8 & $\mathrm{X}$ & $\mathrm{R}$ & $X$ \\
\hline $031 x$ & $06 \mathrm{~W}$ & 285.61 & 285.64 & 606 & 1 & 12 & 619 & 97.9 & 0.2 & 1.9 & $A$ & A & X \\
\hline $031 \mathrm{X}$ & $06 \mathrm{~W}$ & 285.64 & 285.7 & 121 & 6 & 201 & 328 & 36.9 & 1.8 & 61.3 & $\mathrm{~A}$ & $\mathrm{R}$ & $\mathrm{A}$ \\
\hline
\end{tabular}


Huang et al.

Table 2. Continued.

\begin{tabular}{|c|c|c|c|c|c|c|c|c|c|c|c|c|c|}
\hline $031 \mathrm{X}$ & $06 \mathrm{~W}$ & 285.91 & 285.96 & 364 & 0 & 4 & 368 & 98.9 & 0 & 1.1 & $X$ & $X$ & X \\
\hline $032 \mathrm{X}$ & $02 \mathrm{~W}$ & 290.32 & 290.36 & 1 & 0 & 27 & 28 & 3.6 & 0 & 96.4 & X & $X$ & X \\
\hline $032 \mathrm{X}$ & $05 \mathrm{~W}$ & 293.83 & 293.88 & 19 & 0 & 34 & 53 & 35.8 & 0 & 64.2 & $x$ & $x$ & $\mathrm{X}$ \\
\hline $032 \mathrm{X}$ & $05 \mathrm{~W}$ & 294.9 & 294.94 & 221 & 0 & 9 & 230 & 96.1 & 0 & 3.9 & $\mathrm{R}$ & $X$ & $\mathrm{X}$ \\
\hline $032 \mathrm{X}$ & $05 \mathrm{~W}$ & 294.94 & 294.97 & 38 & 0 & 78 & 116 & 32.8 & 0 & 67.2 & $X$ & $X$ & $X$ \\
\hline $033 \mathrm{X}$ & $03 \mathrm{~W}$ & 301.03 & 301.07 & 49 & 1 & 75 & 125 & 39.2 & 0.8 & 60 & $X$ & $X$ & $X$ \\
\hline $034 \mathrm{X}$ & $01 \mathrm{~W}$ & 307.65 & 307.68 & 0 & 0 & 132 & 132 & 0 & 0 & 100 & $X$ & $X$ & $X$ \\
\hline $034 \mathrm{X}$ & $01 \mathrm{~W}$ & 308.14 & 308.15 & 0 & 0 & 8 & 8 & 0 & 0 & 100 & $X$ & $\mathrm{R}$ & $\mathrm{R}$ \\
\hline $034 \mathrm{X}$ & $01 \mathrm{~W}$ & 308.15 & 308.18 & 0 & 0 & 5 & 5 & 0 & 0 & 100 & $X$ & $X$ & $x$ \\
\hline $034 \mathrm{X}$ & $03 \mathrm{~W}$ & 311.05 & 311.09 & 299 & 0 & 0 & 299 & 100 & 0 & 0 & $x$ & $\mathrm{R}$ & $\mathrm{R}$ \\
\hline $034 \mathrm{X}$ & $05 \mathrm{~W}$ & 314.33 & 314.35 & 0 & 0 & 25 & 25 & 0 & 0 & 100 & $\mathrm{X}$ & $\mathrm{R}$ & $\mathrm{X}$ \\
\hline $035 \mathrm{X}$ & $03 \mathrm{~W}$ & 319.92 & 319.96 & 56 & 3 & 31 & 90 & 62.2 & 3.3 & 34.4 & $\mathrm{R}$ & $\mathrm{R}$ & $\mathrm{R}$ \\
\hline $035 \mathrm{X}$ & $03 \mathrm{~W}$ & 320.85 & 320.9 & 1 & 1 & 12 & 14 & 7.1 & 7.1 & 85.7 & $X$ & $X$ & $\mathrm{R}$ \\
\hline $035 \mathrm{X}$ & $04 \mathrm{~W}$ & 321.77 & 321.79 & 264 & 0 & 0 & 264 & 100 & 0 & 0 & $\mathrm{X}$ & $X$ & $X$ \\
\hline $035 \mathrm{X}$ & $05 \mathrm{~W}$ & 322.87 & 322.91 & 79 & 0 & 3 & 82 & 96.3 & 0 & 3.7 & $X$ & $\mathrm{X}$ & $\mathrm{X}$ \\
\hline $040 \mathrm{X}$ & $02 \mathrm{~W}$ & 367.74 & 367.79 & 21 & 0 & 1 & 22 & 95.5 & 0 & 4.5 & $\mathrm{X}$ & $X$ & $X$ \\
\hline $040 \mathrm{X}$ & $03 \mathrm{~W}$ & 368.32 & 368.44 & 4 & 1 & 0 & 5 & 80 & 20 & 0 & $\mathrm{X}$ & $X$ & $\mathrm{X}$ \\
\hline $040 \mathrm{X}$ & $03 W$ & 368.53 & 368.58 & 9 & 1 & 1 & 11 & 81.8 & 9.1 & 9.1 & $X$ & $X$ & $X$ \\
\hline $040 \mathrm{X}$ & $04 \mathrm{~W}$ & 369.79 & 369.84 & 1000 & 0 & 0 & 1000 & 100 & 0 & 0 & $X$ & $X$ & $X$ \\
\hline $041 \mathrm{X}$ & $01 \mathrm{~W}$ & 374.64 & 374.7 & 297 & 2 & 2 & 301 & 98.7 & 0.7 & 0.7 & $X$ & $X$ & $X$ \\
\hline $041 \mathrm{X}$ & $05 \mathrm{~W}$ & 381.57 & 381.62 & 15 & 0 & 35 & 50 & 30 & 0 & 70 & $\mathrm{X}$ & $\mathrm{X}$ & $X$ \\
\hline $042 \mathrm{X}$ & $01 \mathrm{~W}$ & 385.55 & 385.6 & 10 & 0 & 2 & 12 & 83.3 & 0 & 16.7 & $\mathrm{X}$ & $\mathrm{X}$ & $\mathrm{X}$ \\
\hline $042 \mathrm{X}$ & $04 \mathrm{~W}$ & 389.57 & 389.65 & 0 & 3 & 1 & 4 & 0 & 75 & 25 & $X$ & $X$ & $X$ \\
\hline $043 X$ & $03 \mathrm{~W}$ & 397.6 & 397.65 & 0 & 0 & 8 & 8 & 0 & 0 & 100 & $X$ & $X$ & $X$ \\
\hline $044 \mathrm{X}$ & $02 \mathrm{~W}$ & 405.99 & 406.06 & 1 & 0 & 4 & 5 & 20 & 0 & 80 & $X$ & $X$ & $X$ \\
\hline
\end{tabular}



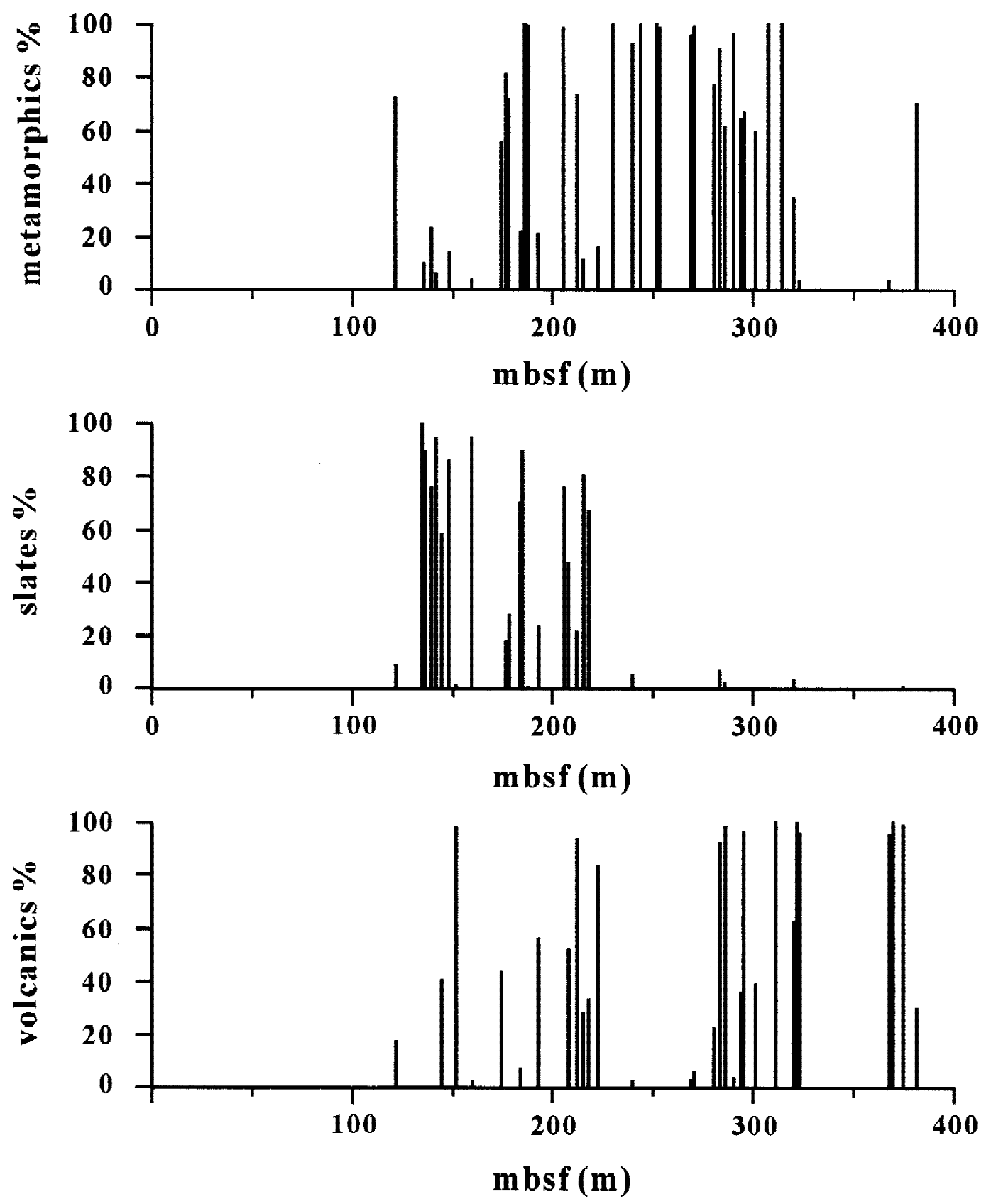

Fig. 3. Composition of volcanic, slate and metamorphic detritus in coarse fraction $(>250 \mu \mathrm{m})$ of Hole 1202D, Leg 195, in southern Okinawa Trough off NE Taiwan. 


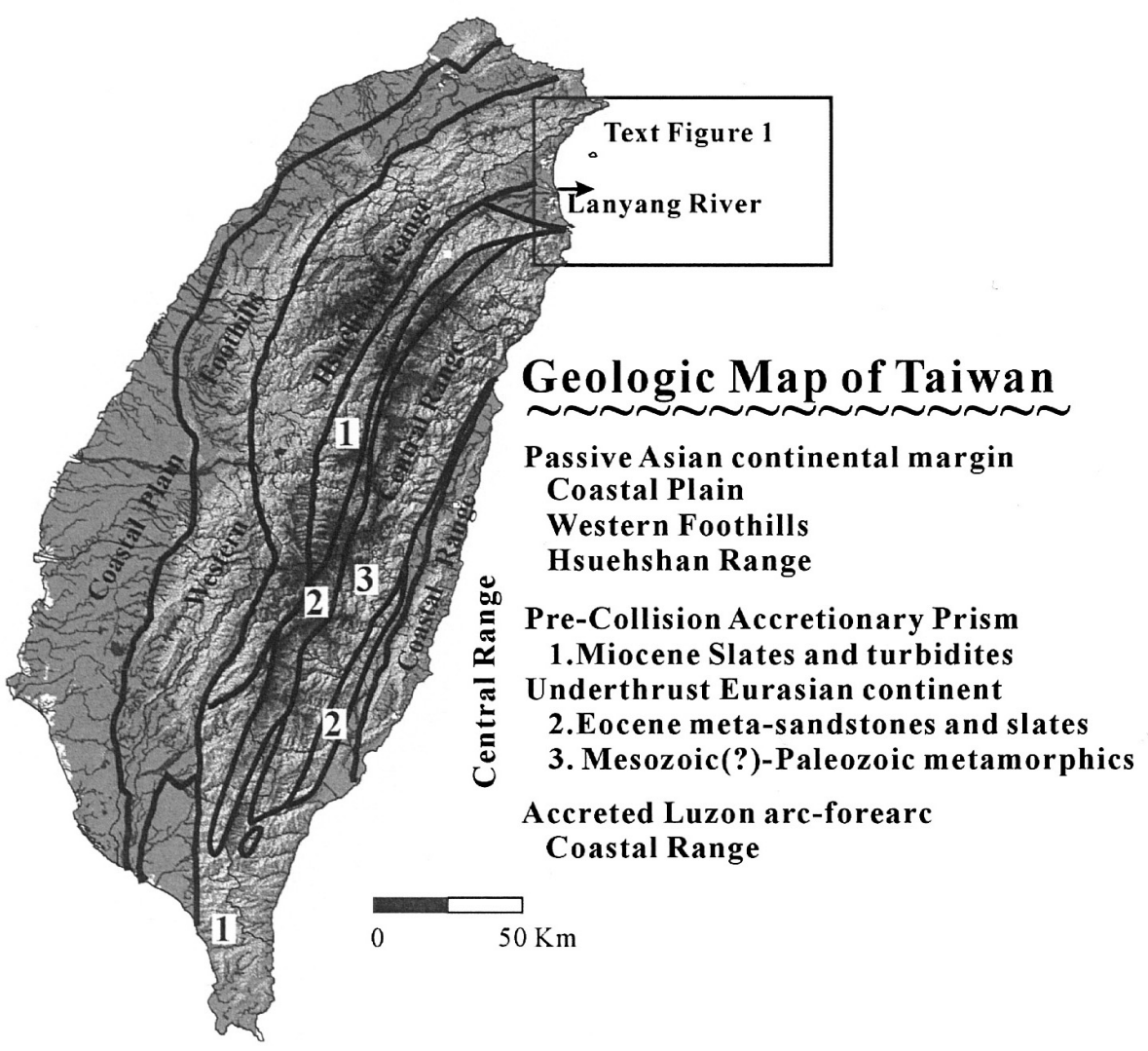

Fig. 4. General geology of Taiwan and location of the Lanyang River in NE Taiwan. The sediments in the southern Okinawa Trough were mostly derived from the Miocene slate belt of pre-collision accretionary prism in the western Central Range and the Early Tertiary-Paleozoic metamorphic basement of the underthrust Eurasian Continent in the eastern Central Range via the Lanyang River and its submarine channel.

submarine channel erosions or by the mass movement of slope failures due to frequent earthquakes induced by plate convergence/collision and extension of the southwestern Okinawa Trough off NE Taiwan.

Acknowledgements The authors appreciate Drs. Peter B. Yuan, B. R. Herbert, J. Baldauf, D. A. Brooks and B. Horan for their assistances in core description during the works in TAMU core laboratory and the Leg 195 Shipboard Scientific Party for drilling and documenting the 
hole. This study was financially supported by NCKU-NSYSU Research Center of Ocean Environment and Technology, National Cheng Kung University, and grants from the National Science Council (NSC91-2116-M006-007; NSC92-2116-M006 -012), Taiwan, R.O.C..

\section{REFERENCES}

Chang, L. S., 1960: A biostratigraphic study of the Miocene in western Taiwan based on smaller foraminifera (Part II: Benthonics). Bull. Geol. Surv. Taiwan., 12, 67-91.

Huh, C. A., C. C. Su, W. T. Liang, and C. Y. Ling, 2004, Linkages between turbidites in the southern Okinawa Trough and submarine earthquakes. Geophys. Res. Lett., 31, L12304.

Huang, C. Y., W. Y. Wu, C. P. Chang, S. Tsao, P. B. Yuan, C. W. Lin, and K. Y. Xia, 1997: Evolution of the pre-collision accretionary prism in the arc-continent collision terrane of Taiwan. Tectonophys., 281, 31-51.

Huang, C. Y., P. B. Yuan, C. W. Lin, T. K. Wang., and C. P. Chang, 2000: Geodynamic processes of Taiwan arc-continent collision and comparison with analogs in Timor, Papua New Guinea, Urals, and Corsica. Tectonophys., 325, 1-21.

Liu, C. S., S. Y. Liu, S. E. Lallemand, N. Lundberg, and D. L. Reed, 1998: Digital elevation model offshore Taiwan and its tectonic implications. Terr. Atmos. Ocean. Sci., 9, 705738.

Kao, H., S. S. Jack Shen, and K. F. Ma, 1998: Transition from oblique subduction to collision: Earthquakes in the southernmost Ryukyu-Taiwan region.J. Geophys. Res., 103, 72117229.

Wei, K. Y., H. S. Mii, and C. Y. Huang, 2005: Age Model and Oxygen Isotope Stratigraphy of Site ODP1202 in the Southern Okinawa Trough, Northwestern Pacific.Terr. Atmos. Ocean. Sci. 16, 1-17.

Shipboard Scientific Party, Site 1202, 2002: In Salisbury, M.H., Shinohara, M., Richter, C., et al., Proc. Init. Repts., 195 1-46 (CD-ROM), Avaiable from: Ocean Drilling Program, Texas A\&M Univ., College Station, TX 77845-9547, USA.

Zhao, M., C. Y. Huang, and K. Y. Wei, 2005: A 28000 Year Sea-Surface Temperature Record of ODP Site 1202B, the Southern Okinawa Trough. Terr. Atmos. Ocean. Sci. 16, 4556.

* Appendix is posted in the TAO Electronic Supplement at the TAO websie (http://tao.cgu.org.tw) 